\section{Pengaturan Posisi Tidur Bayi Berat Lahir Rendah Dapat Menurunkan Kejadian Intoleransi Pemberian Minum Enteral}

\author{
Dyah Dwi Astuti ${ }^{1}$, Yeni Rustina ${ }^{2}$, Fajar Tri Waluyanti ${ }^{2}$ \\ ${ }^{1}$ Politeknik Kementrian Kesehatan Surakarta \\ ${ }^{2}$ Fakultas IImu Keperawatan, Universitas Indonesia
}

\begin{abstract}
Abstrak
Pendahuluan: Intoleransi pemberian minum enteral merupakan masalah yang sering terjadi pada bayi berat lahir rendah. Penelitian bertujuan untuk menganalisis pengaruh pengaturan posisi tidur pada bayi berat lahir rendah terhadap kejadian intoleransi pemberian minum enteral. Metodologi: Desain penelitian adalah kuasi eksperimen pada 20 bayi berat lahir rendah dengan teknik purposive sampling. Bayi dikelompokkan menjadi kelompok intervensi dan kontrol. Bayi pada kelompok kontrol dilakukan intervensi sesuai standar prosedur rutin; sedangkan pada kelompok intervensi dilakukan pengaturan posisi tidur pronasi setelah pemberian minum enteral dan meninggikan bagian kepala tempat tidur 30 derajat selama pemberian minum enteral. Hasil: Analisis uji $\mathrm{t}$ independen dan Fisher's Exact Test menunjukkan bahwa pengaturan posisi tidur dapat menurunkan kejadian desaturasi ( $p$ value $=0,011$ ), distensi abdomen ( $p$ value $=0,017$ ), dan frekuensi muntah ( $p$ value $=0,035$ ). Diskusi: Perawat dapat menjadikan intervensi pengaturan posisi tidur sebagai standar prosedur operasional pada bayi berat lahir rendah yang mengalami intoleransi pemberian minum enteral.
\end{abstract}

Kata kunci: bayi berat lahir rendah, intoleransi pemberian minum enteral, pengaturan posisi tidur

\title{
Sleep Positioning in Low Birth Weight Infants to Reduce Enteral Feeding Intolerance
}

\begin{abstract}
Introduction: Enteral feeding intolerance is a common problem in low birth weight infants. This study aimed to analyze the effects of sleep positioning on low birth weight infants on the occurrence of enteral feeding intolerance. Methodology: This quasi experiment was applied on 20 low birth weight infants with a purposive sampling technique. The infants were grouped into control and intervention. Infants in the control group were given intervention with routine procedures; while those in the intervention group were performed prone sleep positioning after enteral feeding with the head of the bed elevated 30 degrees during the enteral feeding. Results: Independent t-test and Fisher's Exact Test analysis showed that sleep positioning could decrease desaturation event ( $p$ value $=0.011$ ), abdominal distension ( $p$ value $=0.017$ ), and frequency of vomiting ( $p$ value $=0.035$ ). Discussion: Nurses can make sleep positioning as standard operating procedures in low birth weight infants who have enteral feeding intolerance.
\end{abstract}

Keywords: low birth weight, enteral feeding intolerance, sleep positioning

Corresponding Author:

Dyah Dwi Astuti ${ }^{1}$, Letjend Sutoyo, Mojosongo, Surakarta, 57127.Email: dyah.dwi@ui.ac.id 


\section{PENDAHULUAN}

Malnutrisi merupakan masalah yang umum pada bayi berat lahir rendah (BBLR) yang dirawat di rumah sakit. Hasil penelitian yang dilakukan oleh Rafati et al. (2014) menunjukkan bahwa angka kejadian hospital malnutrition pada BBLR yang dirawat di ruang intensif sekitar 15-20\%. Kejadian hospital malnutrition pada BBLR berhubungan dengan defisiensi protein yang dapat mengakibatkan keterlambatan pertumbuhan dan perkembangan, serta kematian (Rafati et al., 2014). Salah satu upaya untuk mencegah terjadinya hospital malnutrition adalah dengan mengoptimalkan pemenuhan kebutuhan nutrisi enteral.

Pemberian nutrisi enteral pada BBLR merupakan suatu tantangan bagi perawat. Pada awal periode adaptasi, BBLR mengalami kehilangan berat badan sebesar $15-20 \%$ yang berhubungan dengan peningkatan kebutuhan energi dari proses respirasi, termoregulasi, sintesis jaringan, dan metabolisme (Carter, 2012). Pada periode awal kehidupan ekstrauterin juga terjadi proses maturasi otak, sehingga terjadi peningkatan kebutuhan nutrisi (Prado \& Dewey, 2014).

Hambatan yang paling sering dialami BBLR dalam pemberian nutrisi enteral adalah terjadinya intoleransi pemberian minum (Zecca et al., 2014). Intoleransi pemberian minum enteral merupakan pengalaman BBLR yang mengalami kesulitan dalam proses ingesti dan digesti, sehingga menyebabkan gangguan perencanaan pemberian minum enteral. Intoleransi pemberian minum enteral ditandai dengan peningkatan residu lambung, muntah, distensi abdomen, dan gangguan buang air besar (BAB). Gejala lebih lanjut adalah adanya apnea, bradikardi, dan instabilitas suhu tubuh (Carter, 2012). Kejadian intoleransi pemberian minum enteral pada BBLR sekitar 16-29\% yang berhubungan dengan imaturitas (Fanaro, 2013).

Salah satu intervensi keperawatan yang dapat diterapkan untuk penanganan intoleransi pemberian minum enteral pada BBLR adalah pengaturan posisi tidur saat pemberian minum enteral (Elser, 2012). Telaah sistematik menunjukkan bahwa pengaturan posisi pronasi dapat menurunkan jumlah residu pada kejadian intoleransi pemberian minum enteral (Dutta et al., 2015). Penelitian ini bertujuan untuk menganalisis pengaruh pemberian posisi tidur BBLR terhadap kejadian intoleransi pemberian minum enteral. Keterbaruan dalam penelitian ini adalah menilai kejadian intoleransi pemberian minum dengan variabel kejadian hipotermia, bradikardia, desaturasi, ada tidaknya $\mathrm{BAB}$, hasil pemeriksaan abdomen, peningkatan lingkar perut, dan frekuensi muntah.

\section{METODE}

Penelitian dilakukan di Ruang Perinatologi Rumah Sakit Pusat Nasional (RSUPN) Cipto Mangunkusumo dan Rumah Sakit Ibu dan Anak (RSAB) Harapan Kita pada tanggal 14 Maret sampai dengan 15 April 2016. Desain penelitian adalah kuasi eksperimen. Sampel penelitian berjumlah 20 BBLR yang dipilih dengan teknik purposive sampling. Bayi dikelompokkan menjadi kelompok intervensi dan kelompok kontrol. Kriteria inklusi penelitian adalah BBLR yang mengalami intoleransi pemberian minum enteral, BBLR dengan berat lahir kurang dari 2.500 gram, memperoleh nutrisi enteral dengan frekuensi 8, 12, atau 24 kali dalam sehari dengan cara gravitasi, dan minimal minum berjumlah $50 \mathrm{ml} / \mathrm{kgbb}$. Kriteria eksklusi penelitian adalah BBLR dengan pneumothoraks, fraktur tulang, atelektasis paru, dan mempunyai kegawatan kardiorespirasi.

BBLR pada kelompok kontrol dilakukan intervensi sesuai dengan standar prosedur rutin yaitu pengaturan posisi tidur supinasi selama pemberian nutrisi enteral. BBLR pada kelompok intervensi dilakukan pengaturan posisi tidur supinasi selama pemberian nutrisi enteral, kemudian setelah pemberian minum enteral dilakukan pengaturan posisi pronasi selama minimal satu jam. Bagian 
kepala tempat tidur pada kelompok intervensi ditinggikan 30 derajat selama pemberian nutrisi enteral. Kejadian intoleransi pemberian minum enteral dievaluasi dengan menilai kejadian hipotermia, bradikardia, desaturasi, ada tidaknya $B A B$, hasil pemeriksaan abdomen, peningkatan lingkar perut, dan frekuensi muntah.

HASIL

Tabel 1. mendeskripsikan distribusi BBLR berdasarkan karakteristik BBLR. Karakteristik BBLR dibedakan berdasarkan usia gestasi, usia kronologis, berat badan lahir, berat badan sekarang, dan jumlah minum enteral. Hasil uji homogenitas dengan analisis Levene's Test menunjukkan bahwa antara kelompok intervensi dan kontrol homogen berdasarkan karakteristik BBLR ( $p$ value $>0,05$ ).

Tabel 1. Karakteristik Bayi Berat Lahir Rendah dan Hasil Uji Homogenitas di RSUPN Cipto Mangunkusumo dan RSAB Harapan Kita Tanggal 14 Maret-15 April $2016(n=20)$

\begin{tabular}{|c|c|c|c|c|c|c|c|}
\hline \multicolumn{2}{|l|}{ Variabel } & Rerata & $\begin{array}{c}\text { Median } \\
\text { (Nilai } \\
\text { Tengah) }\end{array}$ & $\begin{array}{c}\text { Simpang } \\
\text { Baku } \\
\text { (SD) }\end{array}$ & $\begin{array}{c}\text { Rentang (Minimal- } \\
\text { Maksimal) }\end{array}$ & IK 95\% & $\begin{array}{c}\text { Nilai } \\
p\end{array}$ \\
\hline \multicolumn{8}{|c|}{ Usia Gestasi (minggu) } \\
\hline - Intervensi & & 30,67 & 31,00 & 3,162 & $9(25-34)$ & $28,24-33,10$ & $\begin{array}{c}0,83 \\
4 *\end{array}$ \\
\hline - Kontrol & & 30,80 & 31,50 & 3,011 & $9(25-34)$ & $28,65-32,95$ & \\
\hline \multicolumn{8}{|l|}{ Usia Kronologis (hari) } \\
\hline - Intervensi & & 23,89 & 25 & 14,55 & $37(7-44)$ & $12,71-35,07$ & $\begin{array}{c}0,87 \\
4^{*}\end{array}$ \\
\hline - Kontrol & & 21,40 & 18,50 & 14,73 & $41(3-44)$ & $10,86-31,94$ & \\
\hline \multicolumn{8}{|c|}{ Berat Badan Lahir (gram) } \\
\hline - Intervensi & & 1.486 & 1.370 & 524,19 & $1.360(850-2.210)$ & $1.083-1.889$ & $\begin{array}{c}0,58 \\
3 *\end{array}$ \\
\hline $\begin{array}{l}\text { - Kontrol } \\
\text { Berat Badan Sekara }\end{array}$ & (gram) & 1.507 & 1.410 & 470,15 & $1.360(850-2.210)$ & $1.171-1.844$ & \\
\hline - Intervensi & & 1.741 & 1.670 & 440,70 & $1.110(1.110-2.220)$ & $1.402-2.079$ & $\begin{array}{c}0,90 \\
5^{*}\end{array}$ \\
\hline - Kontrol & & 1.756 & 1.810 & 429,54 & $1.160(1.060-2.220)$ & $1.449-2.064$ & \\
\hline $\begin{array}{l}\text { Jumlah Minum } \\
\text { (ml/hari) }\end{array}$ & Enteral & & & & & & \\
\hline - Intervensi & & 164 & 180 & 33 & $110(90-200)$ & $138-189$ & $\begin{array}{c}0,43 \\
7 *\end{array}$ \\
\hline - Kontrol & & 147 & 162 & 38 & $100(80-100)$ & $119-175$ & \\
\hline
\end{tabular}
Keterangan*: Hasil Uji Homogenitas dengan Levene's Test

Tabel 2. mendeskripsikan distribusi BBLR berdasarkan karakteristik BBLR. Karakteristik BBLR dibedakan berdasarkan riwayat asfiksia, riwayat perdarahan intrakranial, terapi prokinetik, terapi oksigen, dan status pemberian air susu ibu (ASI). Hasil uji homogenitas dengan analisis Fisher's Exact Test menunjukkan bahwa antara kelompok intervensi dan kontrol homogen berdasarkan karakteristik BBLR ( $p$ value $>0,05$ ).

Tabel 2. Karakteristik Bayi Berat Lahir Rendah dan Hasil Uji Homogenitas di RSUPN Cipto Mangunkusumo dan RSAB Harapan Kita Tanggal 14 Maret-15 April $2016(n=20)$

\begin{tabular}{llll}
\hline Variabel & Intervensi & Kontrol & Nilai $p$ \\
\hline
\end{tabular}




\begin{tabular}{|c|c|c|c|c|c|}
\hline & f & $\%$ & f & $\%$ & \\
\hline \multicolumn{6}{|l|}{ Riwayat Asfiksia } \\
\hline - Tidak ada riwayat asfiksia & 2 & $20 \%$ & 2 & $20 \%$ & $1,00 *$ \\
\hline - $\quad$ Ada riwayat asfiksia & 8 & $80 \%$ & 8 & $80 \%$ & \\
\hline \multicolumn{6}{|l|}{ Riwayat Perdarahan Intrakranial } \\
\hline - Tidak ada riwayat perdarahan intrakranial & 8 & $80 \%$ & 8 & $80 \%$ & $1,00 *$ \\
\hline - Ada riwayat perdarahan intrakranial & 2 & $20 \%$ & 2 & $20 \%$ & \\
\hline \multicolumn{6}{|l|}{ Terapi Prokinetik } \\
\hline - Memperoleh terapi prokinetik & 4 & $40 \%$ & 3 & $30 \%$ & $1,00 *$ \\
\hline - Tidak memperoleh terapi prokinetik & 6 & $60 \%$ & 7 & $70 \%$ & \\
\hline \multicolumn{6}{|l|}{ Terapi Oksigen } \\
\hline - Tidak memperoleh terapi oksigen & 7 & $70 \%$ & 7 & $70 \%$ & $1,00^{*}$ \\
\hline - Memperoleh terapi oksigen & 3 & $30 \%$ & 3 & $30 \%$ & \\
\hline \multicolumn{6}{|l|}{ Status Pemberian ASI } \\
\hline - Memperoleh ASI & 4 & $40 \%$ & 4 & $40 \%$ & $1,00 *$ \\
\hline - $\quad$ Tidak memperoleh ASI & 6 & $60 \%$ & 6 & $60 \%$ & \\
\hline
\end{tabular}

Keterangan*: Uji Homogenitas Fisher's Exact Test

Tabel 3. mendeskripsikan hasil uji Fisher's Exact Test untuk menganalisis perbedaan kejadian intoleransi pemberian minum enteral. Hasil statistik menunjukkan bahwa tidak terjadi perbedaan kejadian hipotermia, bradikardia, gangguan $B A B$, dan hasil pemeriksaan abdomen antara kelompok intervensi dan kontrol dengan nilai $p$ value lebih dari 0,05. Pada variabel kejadian desaturasi menunjukkan bahwa terdapat perbedaan antara kelompok intervensi dan kontrol dengan $p$ value 0,011 .

Tabel 3. Hasil Uji Perbedaan Kejadian Intoleransi Pemberian Minum di RSUPN Cipto Mangun Kusumo dan RSAB Harapan Kita Tanggal 14 Maret-15 April $2016(n=20)$

\begin{tabular}{|c|c|c|c|c|c|}
\hline \multirow[t]{2}{*}{ Variabel } & \multicolumn{2}{|c|}{ Intervensi } & \multicolumn{2}{|c|}{ Kontrol } & \multirow[t]{2}{*}{ Nilai $p$} \\
\hline & $\mathbf{F}$ & $\%$ & $f$ & $\%$ & \\
\hline \multicolumn{6}{|l|}{ Kejadian Hipotermia } \\
\hline - Tidak & 6 & $60 \%$ & 5 & $50 \%$ & $1,00 *$ \\
\hline - Ya & 4 & $40 \%$ & 5 & $50 \%$ & \\
\hline \multicolumn{6}{|l|}{ Kejadian Bradikardia } \\
\hline - Tidak & 10 & $100 \%$ & 7 & $70 \%$ & $0,211^{*}$ \\
\hline - $Y a$ & 0 & $0 \%$ & 3 & $30 \%$ & \\
\hline \multicolumn{6}{|l|}{ Kejadian Desaturasi } \\
\hline - Tidak & 10 & $100 \%$ & 4 & $40 \%$ & $0,011 *$ \\
\hline - $Y a$ & 0 & $0 \%$ & 6 & $60 \%$ & \\
\hline \multicolumn{6}{|l|}{ Ada/Tidaknya BAB } \\
\hline - $\quad$ Ada BAB & 9 & $90 \%$ & 7 & $70 \%$ & $0,582^{*}$ \\
\hline - Tidak ada BAB & 1 & $10 \%$ & 3 & $30 \%$ & \\
\hline \multicolumn{6}{|l|}{ Abdomen } \\
\hline - Supel & 10 & $100 \%$ & 8 & $80 \%$ & $0,474^{*}$ \\
\hline - Tegang & 0 & $0 \%$ & 2 & $20 \%$ & \\
\hline
\end{tabular}

Keterangan*: Uji Beda dengan Fisher's Exact Test 
Pada tabel 4. menunjukkan hasil uji beda rerata peningkatan lingkar perut dan frekuensi muntah dengan menggunakan uji t independen tidak berpasangan. Hasil statistik menunjukkan bahwa terdapat perbedaan yang bermakna rerata peningkatan lingkar perut dan frekuensi muntah pada kelompok intervensi dan kontrol dengan $p$ value 0,017 dan 0,035. Rerata peningkatan lingkar perut pada kelompok intervensi (rerata $=0,45 \mathrm{~cm}$ ) lebih rendah dibandingkan dengan kelompok kontrol (rerata $=0,90 \mathrm{~cm}$ ) dengan perbedaan rerata 0,45 (IK $95 \%-0,808 \mathrm{~s} . \mathrm{d}-0,091)$. Hasil statistik menunjukkan bahwa rerata frekuensi muntah pada kelompok intervensi (rerata $=0,20$ kali) lebih rendah dibandingkan rerata pada kelompok kontrol (rerata $=1,30$ kali) dengan perbedaan rerata 1,1 kali (IK 95\% -2,11 s.d -0,088).

\section{Tabel 4. Hasil Uji Perbedaan Kejadian Intoleransi Pemberian Minum di RSUPN Cipto Mangun Kusumo dan RSAB Harapan Kita Tanggal 14 Maret-15 April $2016(n=20)$}

\begin{tabular}{lcccc}
\hline & $\begin{array}{c}\text { Rerata } \\
\text { Intervensi }\end{array}$ & $\begin{array}{c}\text { Rerata } \\
\text { Kontrol }\end{array}$ & $\begin{array}{c}\text { Perbedaan Rerata } \\
\text { (IK 95\%) }\end{array}$ & p value \\
\hline $\begin{array}{l}\text { Lingkar Perut } \\
\text { Frekuensi }\end{array}$ & 0,45 & 0,90 & $-0,45(-0,808$ s.d $-0,091)$ & $\mathbf{0 , 0 1 7}$ \\
Muntah & 0,20 & 1,30 & $-1,1(-2,11$ s.d $-0,088)$ & $\mathbf{0 , 0 3 5}$ \\
\hline
\end{tabular}

\section{PEMBAHASAN}

Hasil penelitian menunjukkan mayoritas BBLR adalah bayi prematur. Prematuritas dan berat lahir rendah dapat meningkatkan risiko terjadinya intoleransi pemberian minum enteral yang berhubungan dengan maturasi saluran gastrointestinal (Zubaidah, Rustina, \& Syahreni, 2013). Pada bayi prematur mempunyai fungsi mekanik yang masih imatur meliputi koordinasi mengisap, menelan, dan bernapas. Pada bayi prematur juga terjadi imaturitas fungsi pencernaan yang meliputi fungsi motilitas dan enzim digesti (Fanaro, 2013).

BBLR baik pada kelompok intervensi dan kontrol mayoritas mempunyai riwayat asfiksia, tidak ada perdarahan intrakranial, dan tidak memakai terapi oksigen. BBLR yang mengalami gangguan oksigenasi berisiko untuk mengalami intoleransi pemberian minum enteral. Hal ini berhubungan dengan kejadian hipoksia, sehingga terjadi kompensasi peningkatan aliran darah ke otak dan penurunan aliran darah ke saluran gastrointestinal. Penurunan aliran darah ke saluran gastrointestinal menyebabkan gangguan perfusi dan penurunan peristaltik usus. Penurunan peristaltik usus selanjutnya berdampak pada peningkatan residu lambung (Gomella, Cunningham, \& Eyal, 2013).

Hasil penelitian menunjukkan mayoritas BBLR baik pada kelompok kontrol dan intervensi tidak memperoleh obat prokinetik. Kejadian intoleransi pemberian minum enteral juga dipengaruhi oleh faktor eksternal antara lain pemberian obat prokinetik (Pickler et al., 2015). Pemberian gastroprokinetik seperti erythromycin dapat menurunkan kejadian intoleransi pemberian minum enteral dengan meningkatkan kemampuan pengosongan lambung pada BBLR (Fanaro, 2013).

Mayoritas BBLR dalam penelitian ini tidak memperoleh ASI. Hal tersebut disebabkan karena ibu bayi masih dirawat di ruang intensif dan penolakan orang tua untuk pemberian ASI donor yang berhubungan dengan keyakinan dan budaya. Hasil penelitian yang dilakukan oleh Unger et al. (2015) menyatakan bahwa pemberian kolostrum ibu pada minggu pertama kehidupan BBLR akan 
berefek pada maturasi saluran gastrointestinal. Pemberian ASI pada BBLR dua kali lipat lebih cepat diabsorbsi dibandingkan dengan susu formula, sehingga dapat menurunkan kejadian intoleransi pemberian minum enteral (Underwood, 2013). Perawat perlu melakukan edukasi dengan pendekatan budaya pada orang tua tentang manfaat pemberian ASI pada BBLR yang mengalami intoleransi pemberian minum enteral.

Hasil analisis penelitian menunjukkan bahwa terjadi penurunan kejadian desaturasi pada BBLR yang mengalami intoleransi pemberian minum enteral dengan pengaturan posisi pronasi. Pemberian posisi pronasi memberi kesempatan bagi posterior dinding paru lebih bebas dan tidak terjadi penekanan, sehingga kemampuan peregangan paru dan ventilasi terdistribusi lebih banyak ke area dependen paru. Pada saat yang sama gradient tekanan hidrostatik menyebabkan darah lebih banyak mengalir ke area anterior pada dependen paru, sehingga saturasi oksigen meningkat (Bredemeyer \& Foster, 2015).

Pengaturan posisi pronasi dapat menurunkan frekuensi muntah dan kejadian desaturasi pada BBLR. Kejadian muntah dan desaturasi pada BBLR yang mengalami intoleransi pemberian minum enteral disebabkan karena imaturitas pada lower esophageal sphinter atau LES (Carvaglia et al., 2013). Pada bayi prematur terjadi relaksasi pada LES, sehingga meningkatkan tekanan intragastrik dan terbentuk rongga antara lambung dan esofagus. Cairan dan gas dari fundus lambung mengalir ke esofagus dan menutup jalan napas, sehingga menyebabkan muntah yang disertai bradikardia dan desaturasi (Moore \& Pickler, 2013). Pengaturan posisi pronasi menyebabkan LES berkontraksi, sehingga menurunkan kejadian intoleransi pemberian minum enteral pada BBLR.

Rerata peningkatan lingkar perut pada BBLR yang dilakukan pengaturan posisi lebih rendah, artinya risiko terjadinya distensi abdomen lebih rendah. Distensi abdomen pada BBLR yang mengalami intoleransi pemberian minum enteral disebabkan oleh gangguan pada proses perjalanan mekonium dan penurunan bising usus (Sharma et al., 2013). Posisi pronasi meningkatkan pertukaran gas dengan menurunkan tekanan pleura dan meningkatkan area ventilasi rongga diafragma, sehingga dapat menurunkan distensi abdomen. Posisi pronasi juga dapat menurunkan retensi pertukaran gas di saluran gastrointestinal, sehingga meningkatkan perfusi saluran gastrointestinal dan meningkatkan motilitas usus (Sangers et al., 2013).

Penelitian tentang pengkajian intoleransi pemberian minum dengan pengukuran lingkar perut dilakukan oleh Kaur et al. (2015) dengan metode randomized controlled trial. Penelitian bertujuan membandingkan pengkajian intoleransi pemberian minum antara pengukuran lingkar perut dengan pengecekan residu lambung. Hasil penelitian menunjukkan bahwa pada kelompok dengan pengkajian lingkar perut lebih cepat mencapai pemberian minum penuh, lebih singkat mengalami intoleransi pemberian minum dan pemberian nutrisi parenteral, serta kultur sepsis lebih sedikit.

Hasil penelitian ini sesuai dengan penelitian yang dilakukan oleh Chen et al. (2013). Penelitian tersebut bertujuan menggambarkan pola perubahan residu lambung dari waktu ke waktu dalam posisi pronasi dan supinasi terhadap residu lambung pada BBLR. Pengumpulan data dilakukan dengan cara bayi 3 hari diberikan posisi supinasi dan 3 hari dalam posisi pronasi. Residu lambung lebih sedikit pada posisi pronasi dibandingkan posisi supinasi dan penurunan residu lambung lebih cepat pada setengah jam setelah makan.

Penelitian ini juga didukung oleh hasil telaah sistematik Dutta et al. (2015). Telaah sistematik tersebut bertujuan menentukan standar atau protokol pemberian minum enteral pada BBLR dengan menentukan tingkat rekomendasi berdasarkan standar evidence based. Telaah sistematik merekomendasikan pemberian posisi pronasi selama 30-60 menit untuk menurunkan residu lambung dan risiko intoleransi pemberian minum. 
Penelitian lainnya dilakukan oleh Visscher et al. (2015) yang bertujuan untuk menentukan posisi yang tepat pada BBLR yang mengalami kesulitan minum. Kriteria BBLR adalah usia gestasi kurang dari 37 minggu yang mengalami kesulitan pemberian minum seperti distensi abdomen, gastroesophageal reflux disease, perforasi intestinal, necrotizing enterocolitis, dan obstruksi intestinal. Penelitian merekomendasikan pengaturan posisi pronasi untuk meningkatkan tidur pada BBLR yang mengalami kesulitan pemberian minum.

\section{SIMPULAN DAN SARAN}

Simpulan

Pengaturan posisi tidur pronasi dengan meninggikan bagian kepala tempat tidur 30 derajat dapat menurunkan frekuensi muntah, menurunkan terjadinya desaturasi, dan distensi abdomen.

Saran

Perawat dapat menerapkan intervensi pengaturan posisi sebagai standar prosedur operasional pada BBLR yang mengalami intoleransi pemberian minum enteral.

\section{KEPUSTAKAAN}

Bredemeyer, S.L., \& Foster, J.P. (2012). Body positioning for spontaneusly breathing preterm infants with apnoea (review). The Cochrane Collaboration, 6, 1-40.

Carter, B.M. (2012). Feeding intolerance in preterm infants and standard of care guidelines for nursing assessments. Newborn \& Infant Nursing Reviews, 12 (4), 187-201.

Carvaglia, L., Martini, S., Aceti, A., Arcuri, S., Rossini, R., \& Faldella, G. (2013). Nonpharmacological management of gastroesophageal reflux preterm infants. BioMed Research International, 7 , 1-7.

Chen, S-S., Tzeng, Y-L., Gau, B-S., Kuo, P-C., \& Chen, J-Y. (2013). Effects of prone and supine positioning on gastric residuals in preterm infants: A time series with cross-over study. International Journal of Nursing Studies, 50, 1459-1467.

Dutta, S., Sigh, B., Chessell, L., Wilson, J., Janes, M., McDonald, K., ..., Fusch, C. (2015). Guidelines for feeding very low birth weight infants. Nutrients, 7, 423-442.

Elser, H.E. (2012). Positioning after feedings: What is the evidence to reduce feeding intolerances? Advances in Neonatal Care, 12 (3), 172-175.

Fanaro, S. (2013). Feeding intolerance in the preterm infant. Early Human Development, 89, 513520.

Gomella, T.L., Cunningham, M.D., \& Eyal, F. (2013). Neonatology: Management, procedures, oncall problems, diseases, and drugs. New York: Mc Graw Hill Education.

Kaur, A., Kler, N., Saluja, S., Modi, M., Soni, A., Thakur, A., \& Garg, P. (2015). Abdominal circumference or gastric residual volume as measure of feed intolerance in VLBW infants. J Pediatr Gastroenterol Nutr, 60 (2), 259-63.

Moore, T.A., \& Pickler, R.H. (2013). Evaluating the precision of clinical assessments for feeding intolerance. Newborn \& Infant Nursing Review, 13, 184-188. 
Pickler, R.H., Wetzel, P.A., Meinzen-Derr, J., Tubbs-Cooley, H.L., \& Moore, M. (2015). Patterned feeding experience for preterm infants: Study protocol for a randomized controlled trial. Bio Med Central, 16 (255), 1-9.

Prodo, L.E., \& Dewey, K. (2014). Nutrition and brain development in early life. Nutrition Reviews, $72(4), 267-284$.

Rafati, M.R., Nakhshab, M., Ghaffari, V., Mahdavi, M.R., \& Pharm, M.S. (2014). Evaluation of nutritional status in a neonatal intensive care unit at a teaching hospital. Iranian Journal of Neonatology, 5 (4), 24-29.

Sangers, H., Jong, P.M.D., Mulder, S.E., Stigter, G.D., Berg, C.M.V.D., Pas, A.B.T., \& Walther, F.J. (2013). Outcomes of gastric residuals whilst feeding preterm infants invarious body positions. Journal of Neonatal Nursing, 19, 337-341.

Sharma, P., Nangia, S., Tiwari, S., Goel, A., Singla, B., \& Saili, A. (2013). Gastric lavage for preventing of feeding problems in neonates with meconium-stained amniotic fluid: A randomised controlled trial. Paediatrics and International Child Health, 0 (0), 1-6.

Underwood, M.A. (2013). Human milk for the premature infant. Pediatr Clin North Am, 60 (1), 189-207.

Unger, S., Stintzi, A., Shah, P., Mack, D., \& O'Connor, D.I. (2015). Gut microbiota of the very low birth weight infant. Pediatric Resiarch, 7 (1), 205-213.

Visscher, M.O., Lacina, L., Casper, T., Dixon, M., Harmeyer, J., Haberman, B., ..., \& Simakajomboon, N. (2015). Conformational positioning improves sleep in premature infants with feeding difficulties. The Journal of Pediatrics, 166 (1), 44-48.

Zecca, E., Costa, S., Barone, G., Giordano, L., Zecca, C., \&Maggio, L. (2014). Proactive enteral nutrition in moderately preterm small for gestational age infants: A randomized clinical trial. The Journal of Pediatrics, 165 (6), 1135-1139.

Zubaidah, Rustina, Y., \& Syahreni, E. (2013). Penerapan model konservasi Levine pada bayi prematur dengan intoleransi minum. Jurnal Keperawatan Anak, 1 (2), 65-72. 